\title{
Correction to: Casticin inhibits nasopharyngeal ․․… carcinoma growth by targeting phosphoinositide 3-kinase
}

Jingxian Liu', Jinghong Yang ${ }^{1}$, Yuhe Hou' ${ }^{1}$, Zhenwei Zhu ${ }^{1}{ }^{2}$, Jie He ${ }^{1}$, Hao Zhao ${ }^{1}$, Xidong Ye ${ }^{1}$, Dengke Li ${ }^{1}$, Zhaohui $\mathrm{Wu}^{1}$, Zhongxi Huang ${ }^{1,2}$, Bingtao Hao ${ }^{1,3^{*}}$ and Kaitai Yao ${ }^{1,2^{*}}$

\section{Correction to: Cancer Cell Int (2019) 19:348}

https://doi.org/10.1186/s12935-019-1069-6

Following publication of the original article [1], we were notified that the control group in the left panel of Figure $1 \mathrm{c}$ was incorrect, the labelling of the control group in Figure 1e was inconsistent.

Corrected Fig. 1 can be found below:
Also, the legend for Figure $2 \mathrm{f}$ needs to read: "Levels of expression of apoptosis related proteins BCL2 and BAX in S18 cells with a gradient of casticin concentrations ( 0 , $1,2,4 \mu \mathrm{M})$, and C666-1 with a gradient of casticn concentrations $(0,2,4$ or $8 \mu \mathrm{M})$ analyzed by Western blotting."

These changes don't affect any of the conclusions. The authors apologise for any inconvenience. 
a<smiles>COc1ccc(-c2oc3cc(OC)c(OC)c(O)c3c(=O)c2OC)cc1O</smiles>

b

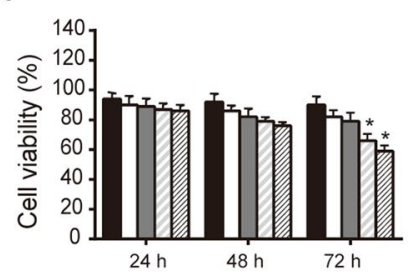

d

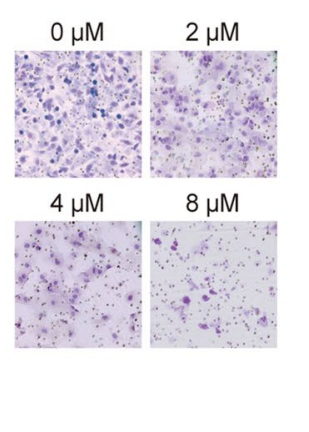

f

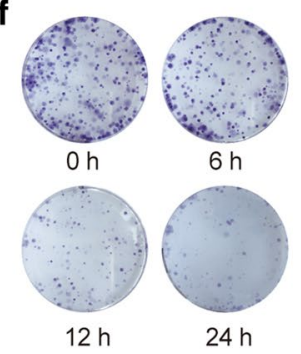

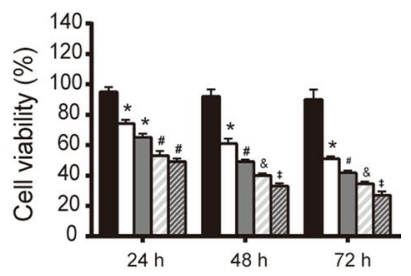

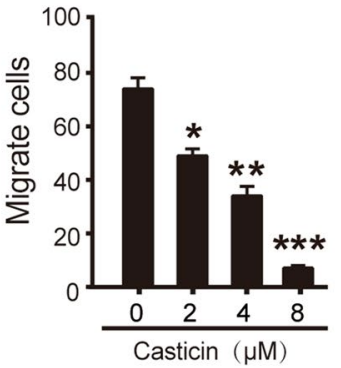

e
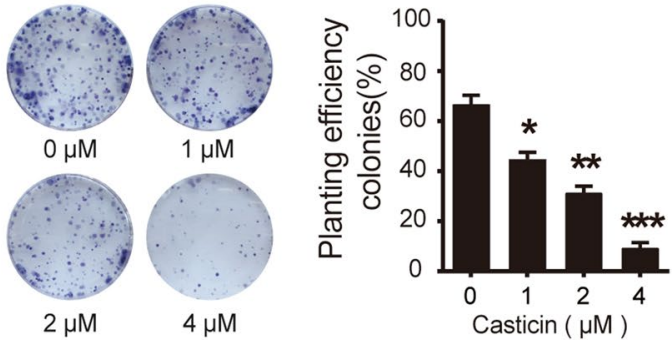

NS

Casticin

g

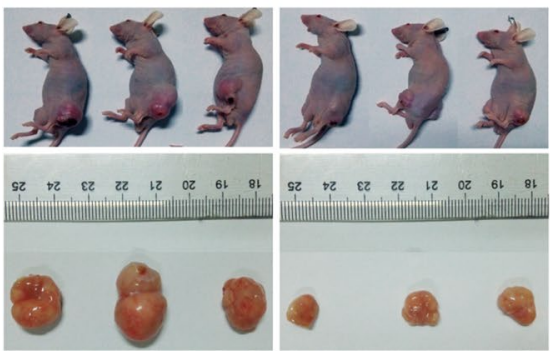

h

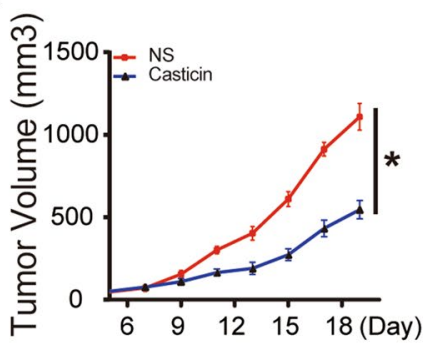

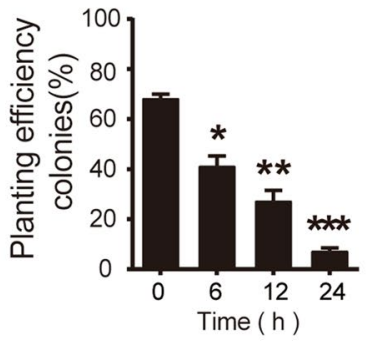

i

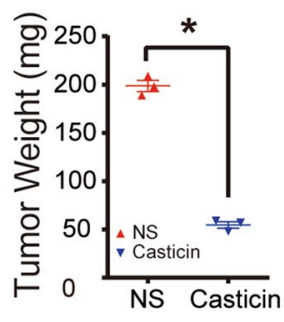

Fig. 1 Casticin inhibits the proliferation and viability of NPC cells in vitro and in vivo. a The chemical structure of casticin. b NP69 and S18 cells were treated with a gradient of casticin concentrations $(0,2,4,8,16 \mu \mathrm{M})$ for 24,48 or $72 \mathrm{~h}$. Cell viability was assessed using the CCK-8 assay. The data are presented as the mean \pm SEM, ${ }^{*} p<0.05$ versus $0 \mu \mathrm{M} ;{ }^{*} p<0.05$ versus $2 \mu \mathrm{M} ;{ }^{*} p<0.05$ versus $4 \mu \mathrm{M} ;{ }^{\ddagger} p<0.05$ versus $8 \mu \mathrm{M}$. c Casticin inhibits migration of $\mathrm{S} 18$ cells in the wound healing assay. White dashed lines indicate the wound edge. The residual gap between the migrating cells from the opposite edges of the wound is represented by a percentage of the initial scratch area. Corresponding graph shows the mean width of the injury lines of three independent experiments (right). All data are presented as the mean \pm standard deviation. ${ }^{* *} p<0.01$ versus DMSO. $\mathbf{d}$ Casticin inhibits migration of S18 cells in the Transwell assay. Corresponding graphs in the panel on the right show the mean numbers of cells per high-power field (HPF) from five independent areas. All data are presented as the mean \pm standard deviation. ${ }^{*} p<0.05$ versus $0 \mu M_{,}{ }^{* *} p<0.01$ versus $2 \mu M$, and ${ }^{* * *} p<0.001$ versus 4 $\mu \mathrm{M}$. e, $\mathbf{f}$ Colony formation of $\mathrm{S} 18$ cells post-treatment with casticin. Cells were exposed to $0,1,2$, and $4 \mu \mathrm{M}$ casticin for $12 \mathrm{~h}$ or were exposed to a fixed level of $1 \mu \mathrm{M}$ casticin for different time periods $(0,6,12$, and $24 \mathrm{~h}$ ) and were then allowed to form colonies for approximately 10 days. Corresponding graphs show the mean number of colonies in different groups for three independent experiments (right). All data are presented as the mean \pm standard deviation. Right panel of $\mathbf{e}^{*} \mathrm{p}<0.05$ versus $0 \mu \mathrm{M}$, ${ }^{* *} p<0.01$ versus $1 \mu \mathrm{M}$, and ${ }^{* * *} \mathrm{p}<0.001$ versus $2 \mu \mathrm{M}$. Right panel of $\mathbf{f}{ }^{*} \mathrm{p}<0.05$ versus $0 \mathrm{~h}$, ${ }^{* *} p<0.01$ versus $6 \mathrm{~h}$, and ${ }^{* * *} p<0.001$ versus $12 \mathrm{~h} ; \mathbf{g}$ Casticin (10\% DMSO +90\% physiological saline, $40 \mathrm{mg} / \mathrm{kg}$ ) was injected into nude mice every day for 12 days starting 6 days after inoculation with 5 million S18 cells. h Tumour volume was periodically measured for each mouse, and the growth curve was plotted. i Tumours were excised from the animals and weighed. ${ }^{*} p<0.05$ versus NS 


\section{Author details}

${ }^{1}$ Guangdong Provincial Key Laboratory of Tumor Immunotherapy, Cancer Research Institute, School of Basic Medical Sciences, Southern Medical University, Guangzhou 510515, Guangdong, People's Republic of China. ${ }^{2}$ Shenzhen Hospital, Southern Medical University, Shenzhen 518000, Guangdong, People's Republic of China. ${ }^{3}$ Shunde Hospital, Southern Medical University, Shunde 528300, Guangdong, People's Republic of China.

Published online: 26 February 2021

\section{Reference}

1. Liu J, Yang J, Hou Y, Zhu Z, He J, Zhao H, Ye X, Li D, Wu Z, Huang Z, Hao B, Yao K. Casticin inhibits nasopharyngeal carcinoma growth by targeting phosphoinositide 3-kinase. Cancer Cell Int. 2019;19:348. https://doi. org/10.1186/s12935-019-1069-6.

\section{Publisher's Note}

Springer Nature remains neutral with regard to jurisdictional claims in published maps and institutional affiliations.
Ready to submit your research? Choose BMC and benefit from:

- fast, convenient online submission

- thorough peer review by experienced researchers in your field

- rapid publication on acceptance

- support for research data, including large and complex data types

- gold Open Access which fosters wider collaboration and increased citations

- maximum visibility for your research: over $100 \mathrm{M}$ website views per year

At BMC, research is always in progress.

Learn more biomedcentral.com/submissions 